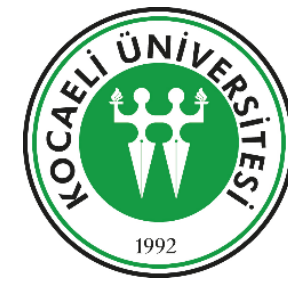

Kocaeli Üniversitesi Sağlık Bilimleri Dergisi

Original Article / Özgün Araştırma

http://dergipark.gov.tr/kusbed

\title{
INVESTIGATION OF THE PREVALENCE OF TONSILLOLITH IN THE AEGEAN REGION USING CONE-BEAM COMPUTED TOMOGRAPHY
}

\author{
KONIKK IŞINLI BILLGISAYARLI TOMOGRAFİ KULLANILARAK EGE BÖLGESI'NDE TONSÍLOLITT \\ PREVALANSININ ARAŞTIRILMASI
}

Fahrettin Kalabalık ${ }^{1}$ (DCeren Çiftçi ${ }^{1}$ @(Dmre Aytuğar ${ }^{1 *}$

${ }^{1}$ Izmir Katip Celebi University, Faculty of Dentistry, Department of Oral and Maxillofacial Radiology, Izmir, Turkey

ORCID iD: Fahrettin Kalabalık: 0000-0001-7084-4995; Ceren Çiftçi: 0000-0003-4359-9095; Emre Aytuğar: 0000-0002-0686-6476

*Corresponding Author / Sorumlu Yazar: Emre Aytuğar e-mail / e-posta: emreaytugar@gmail.com

Received / Geliş Tarihi: 01.07.2019

Accepted / Kabul Tarihi: 03.09.2019

Published / Yaym Tarihi: 06.09.2019

\begin{abstract}
Objective: The purpose of this research was to investigate the prevalence rate and characteristics of tonsilloliths in a Turkish population sample living in the Aegean region of Turkey using cone-beam computed tomography.

Methods: Three hundred ninety-nine consecutive cone-beams computed tomography data was obtained at the Department of Oral and Dentomaxillofacial Radiology were retrospectively analyzed for the characteristics and presence of tonsilloliths. The subjects were divided into three groups according to age: (1) age $\leq 20$ years; (2) age 21-40 years; (3) age $\geq 41$ years. The correlation between subject demographics and the characteristics (number and prevalence) of tonsilloliths was investigated.

Results: The prevalence rate of palatine tonsilloliths in 399 subjects (184 males, 215 females; mean age of 34.3 years) was $25.8 \%$; the prevalence showed no significant difference between male and female genders $(p=0.57)$. A positive correlation was observed between the number of tonsillotihs and age $(p=0.002)$. Tonsillar calcification was significantly more common in Group 3 than Group 1 and 2, while it was significantly lower in Group 1 than the other groups $(p=0.036)$.

Conclusion: According to our results, tonsilloliths affect approximately a quarter of the Aegean population. Tonsilloliths are age-related but sexindependent. These calcifications are more common in people older than 40 years of age.
\end{abstract}

Keywords: Cone-beam computed tomography, palatine tonsil, calcification

Öz

Amaç: Bu çalışmanın amacı, konik ışınlı bilgisayarlı tomografi kullanarak Ege Bölgesi’nde yaşayan bir Türk popülasyonundaki tonsillolit prevalansını ve özelliklerini araştırmaktır.

Yöntem: Fakültemiz Ağız, Diş ve Çene Radyolojisi Anabilim Dalı arşivindeki 399 hastanın konik ışınlı bilgisayarlı tomografi kayıtları retrospektif olarak incelenmiştir. Tonsillolit prevalansı ve özellikleri değerlendirilmiştir. Hastalar yaşlarına gore: (1) $\leq 20$ yaş; (2) 21-40 yaş; (3) yaş $\geq 41$ yaş olacak şekilde üç gruba ayrılmıştır: Hastaların demografik özellikleri ile tonsillolitin görülme sıklığı ve sayısı arasındaki ilişki araştırılmıştır.

Bulgular: Toplam 399 hasta (184 erkek, 215 kadın; ortalama yaş 34,3) incelendiğinde tonsillolit prevalans1 \%25,8 olarak hesaplanmıştır. Erkek ve kadın hastalar arasında tonsilolit görülme sıklığı bakımından anlamlı bir farklılık görülmemiştir $(p=0,57)$. Tonsillolit sayısı ile yaş arasında pozitif bir korelasyon saptanmıştır $(p=0,002)$. Tonsiller kalsifikasyon oranı Grup 3'te Grup 1 ve 2'den anlamlı derecede fazlayken, Grup 1'de diğer gruplardan anlamlı derecede düşük bulunmuştur $(p=0,036)$.

Sonuç: Çalışmada elde edilen bulgulara göre tonsillolit Ege nüfusunun yaklaşık dörtte birini etkilemektedir. Tonsillolit görülme sıklığı yaşa bağlı değişim göstermekte ancak cinsiyet faktöründen etkilenmemektedir. Bu kalsifikasyonlar en fazla 40 yaş üzerindeki hastalarda görülmektedir.

Anahtar Kelimeler: Konik ışınlı bilgisayarlı tomografi, palatin tonsil, kalsifikasyon 


\section{Introduction}

Tonsilloliths are unusual calcific concretes arising from tonsillar crypts in or around the tonsils. They are composed of calcium salts such as oxalate, hydroxyapatite, magnesium salts, and calcium carbonate apatite. Chronic infection of the tonsils results in tonsilloliths which are constituted by serum, desquamated epithelium, nutrient debris, and bacterium colonies. ${ }^{1}$

Tonsilloliths vary in size; they may measure a millimeter up to a centimeter. ${ }^{2}$ They can be round or irregular, single or multiple, and unilateral or bilateral. ${ }^{3,4}$ Normally, small tonsilloliths are asymptomatic but when they become larger in size they can cause pain, and halitosis, foreign body reaction in the pharynx, and peritonsillar abscesses. ${ }^{1}$ The asymptomatic tonsilloliths can be detected during the radiologic examination incidentally.

Some tonsilloliths are located in the palatine tonsillar region and the posterior nasopharyngeal wall and are called nasopharyngeal tonsilloliths. ${ }^{5,6}$ On dental panoramic radiographs, they can be seen in the midline of the mandibular ramus as a large number of small radiopaque groups with illdefined margins. ${ }^{4}$ Nevertheless, it's hard to distinguish them from the other anatomical structures located in the mandibular ramus and other calcifications superimposed with the ramus. ${ }^{7}$ Computed Tomography (CT) may be a better option to investigate the prevalence and characteristics of tonsilloliths. ${ }^{8}$ Recently, Cone-Beam Computed Tomography (CBCT) has been increasingly used as a diagnostic method in dentistry. It provides high-quality multi-plane images using lower radiation doses than CT. ${ }^{9}$ Although CBCT has a lower soft tissue contrast, it is superior to conventional radiographic examination in terms of detecting tonsilloliths. ${ }^{10}$

The prevalence of tonsilloliths may vary according to geographical, racial and nutritional factors. There have been many studies on the prevalence of tonsilloliths in different geographies. ${ }^{11}$ However, no studies have assessed the prevalence of tonsillolith in the Aegean Region population.
As such, the purpose of this study was to investigate the prevalence rate and characteristics of tonsilloliths in the Aegean region using CBCT.

\section{Methods}

We designed a retrospective study consisting of images of 399 subjects (184 male, 215 female) who visited Izmir Katip Celebi University, School of Dentistry. All individuals in our department's CBCT archive have provided written consent regarding the use of their radiologic data for scientific research. The age of the research population ranged from 11 to 84 years, with a mean age of 34 years.

Cone-Beam Computed Tomography scans were obtained using New Tom 5G (QR Srl, Verona, Italy). Voxel size and slice thickness were $0.2 \mathrm{~mm}$ and $1.0 \mathrm{~mm}$, respectively. 110 $\mathrm{kVp}, 1-20 \mathrm{~mA}, 15 \times 12 \mathrm{~mm}$ FOV were the imaging parameters. The CBCT scans had been prescribed for various reasons such as implant planning, third molar extraction, orthodontic treatment, etc. None of the CBCT scannings in the present research were prescribed for reasons involving the presence of tonsilloliths. The images were examined using NNT software (QR srl, Verona, Italy) on a medical monitor (Radiforce MX270W; Eizo Radiforce, Ishikawa, Japan) in a dark room by a trained examiner.

The images with poor quality and unsuitable field of view for detection of tonsilloliths were excluded. Included images were evaluated for the presence or absence of tonsillolith by an investigation using a multiplanar view. In the axial section (Figure 1A), which is considered the best diagnostic image for detection of tonsillar calcifications, the medial region of the mandibular ramus adjacent to the lateral wall of the oropharyngeal airway was evaluated. The presence or absence of calcifications was confirmed in sagittal (Figure 1B) and coronal (Figure 1C) sections.
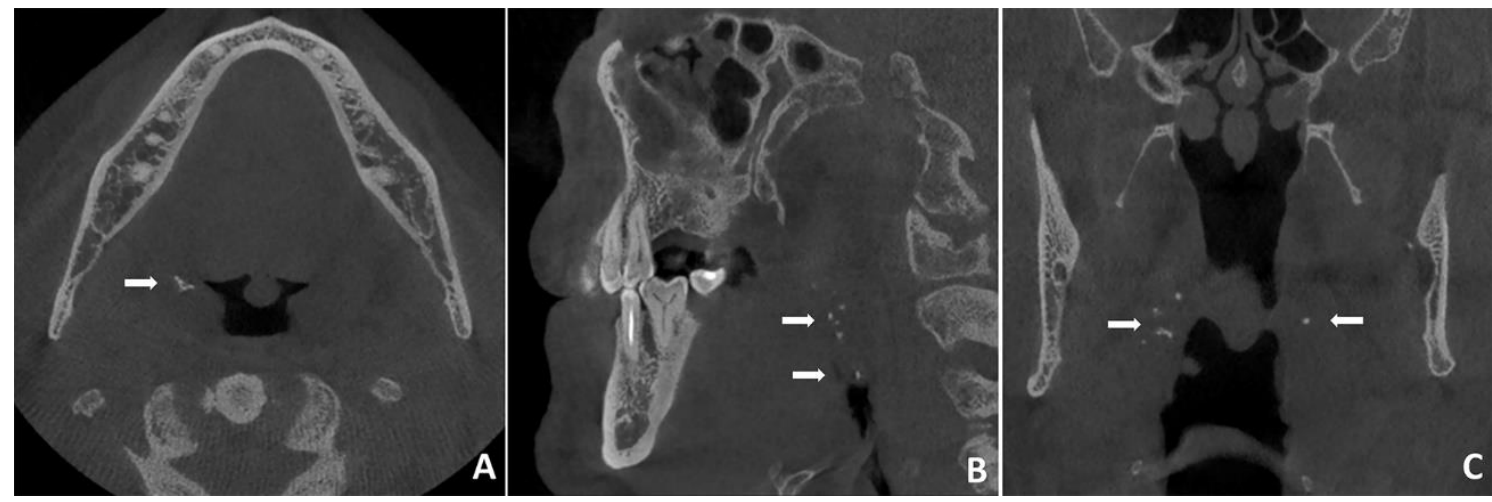

Figure 1 (A-B-C). Multiple tonsilloliths are shown with white arrows in axial (A), sagittal (B), and coronal (C) CBCT images of the same patient

The images with calcification were evaluated according to age, gender, and unilateral or bilateral locations. Scans involving oropharynx and nasopharynx were reviewed looking for calcifications within the region of the palatine tonsils. The CBCT evaluations were divided into three groups according to the subjects' ages: younger than 21 years (Group 1); 21-40 years (Group 2); older than 40 years old (Group 3). The characteristics of tonsilloliths were compared among these groups.

\section{Statistical Analysis}

Statistical analysis was performed by using SPSS v.22 software (IBM, Chicago, IL, USA). Descriptive statistics including the means and standard deviations for each measurement were calculated for age groups and genders. Mann-Whitney U test, Chi-square test, and Spearman's correlation test were used for statistical analysis. The level of statistical significance was established at a $p<0.05$. 


\section{Results}

A total number of 399 CBCT images were evaluated for the presence of tonsillar calcifications. The subjects were aged between 11 years and 84 years (mean age: 34.34 years). Tonsilloliths were found in 103 out of 399 subjects (25.8\%). They were detected bilaterally in 42 subjects $(40.78 \%)$ and unilaterally in 61 subjects $(59.22 \%)$. The number of subjects with unilateral tonsillolith was significantly higher than those with bilateral tonsilloliths. $(p=0.001)$.

Tonsilloliths were unilaterally detected on the right side in 28 subjects, and on the left side in 33 subjects. Mann-Whitney U test showed that there was no significant difference in number between the right and left sides in both males and females $(p=0.58)$.

Subject population consisted of $184(46.1 \%)$ males and 215 $(53.9 \%)$ females. The prevalence rate according to gender was $27.0 \%$ for females and $24.5 \%$ for males. There was no significant difference in the tonsillolith prevalence regarding $\operatorname{sex}(p=0.57)$ (Table 1).

Table 1. Prevalence of tonsilloliths in males and females

\begin{tabular}{l|ccc}
\hline Gender & $\begin{array}{c}\text { Absence } \\
\mathbf{n}(\%)\end{array}$ & $\begin{array}{c}\text { Presence } \\
\mathbf{n}(\%)\end{array}$ & $\boldsymbol{p}$ \\
\hline Male & $139(75.5)$ & $45(24.5)$ & \\
Female & $157(73.0)$ & $58(27.0)$ & 0.57 \\
Total & $296(74.2)$ & $103(25.8)$ & \\
\hline
\end{tabular}

Chi-Square Tests, n: Number of cases

The number of tonsilloliths per palatine tonsil varied in between 1 to 24 . A single tonsillolith was found in 42 tonsils $(40.78 \%)$, two tonsilloliths in 21 tonsils $(20.39 \%)$, three in 11 $(10.68 \%)$, four in $7(6.80 \%)$, five in $9(28.74 \%)$, and more than five in $13(12.62 \%)$ (Table 2).

Table 2. Number of tonsilloliths per palatine tonsil

\begin{tabular}{l|cc}
\hline Number of tonsilloliths & Number of tonsils & $\boldsymbol{\%}$ \\
\hline $\mathbf{1}$ & 42 & 40.78 \\
$\mathbf{2}$ & 21 & 20.39 \\
$\mathbf{3}$ & 11 & 10.68 \\
$\mathbf{4}$ & 7 & 6.80 \\
$\mathbf{5}$ & 9 & 8.74 \\
$>\mathbf{5}$ & 13 & 12.62 \\
Total & 103 & 100 \\
\hline
\end{tabular}

The age range for subjects with tonsilloliths was $12-80$ years. A positive correlation was observed between the number of tonsilloliths and age $(p<0.05)$; the prevalence of tonsilloliths increased with age (Table 3 ).

Table 3. Correlation between the number of tonsilloliths with age.

\begin{tabular}{l|cc}
\hline \multirow{2}{*}{ Number of Tonsillolit } & \multicolumn{2}{|c}{ Age } \\
\cline { 2 - 3 } & $\mathbf{r}$ & $\boldsymbol{p}$ \\
& 0.155 & $0.002 * *$ \\
\hline
\end{tabular}

Spearman's correlation analysis

$r$ : Spearman correlation coefficient, $* * p<0.01$
The investigation for the age distribution of the subjects with tonsilloliths revealed that tonsillar calcification was significantly more common in Group 3 than Group 1 and 2, while it was significantly lower in Group 1 than the other groups $(p=0.036)$ (Table 4$)$.

Table 4. Age distribution of tonsillar calcifications

\begin{tabular}{l|lcc}
\hline $\begin{array}{c}\text { Age } \\
\text { Groups }\end{array}$ & $\begin{array}{c}\text { Absence } \\
\mathbf{n}(\boldsymbol{\%})\end{array}$ & $\begin{array}{c}\text { Presence } \\
\mathbf{n}(\%)\end{array}$ & $\boldsymbol{p}$ \\
\hline Group 1 & $107(36.1)$ & $25(24.3)$ & \\
Group 2 & $84(28.4)$ & $28(27.2)$ & $0.036^{*}$ \\
Group3 & $105(35.5)$ & $50(48.5)$ & \\
Total & $296(100)$ & $103(100)$ & \\
\hline
\end{tabular}

Chi-Square Tests, n: Number of cases, ${ }^{*} p<0.05$

\section{Discussion}

Tonsilloliths are one of the most common soft tissue calcifications in the maxillofacial region. ${ }^{10,12}$ They can be detected by physical examination and radiological observation. In panoramic radiography, they seem as radiopaque shadows over the middle of the ascending mandibular ramus. ${ }^{13}$ However, panoramic radiography fails in the detection and exact localization of the soft-tissue calcifications adjacent to bone. ${ }^{14}$ Depending on the location of calcification, they can be interpreted as phleboliths, cysticercosis, foreign bodies, sialoliths, calcified lymph nodes, osteomas, odontomas, stylohyoid ligament mineralization, carotid artery arteriosclerosis, or dystrophic calcifications in acne scars. ${ }^{15}$ In addition, the calcifications outside the focal trough seem blurred, reduced in size or magnified and sometimes distorted. ${ }^{16}$ The superimposition of the anatomical structures in the panoramic radiography creates challenges in the interpretation of the images. ${ }^{8}$

The differentiation of soft tissue calcifications can be done readily by three-dimensional imaging methods such as $\mathrm{CT}$ and CBCT.${ }^{14,15} \mathrm{CT}$ is the most appropriate and accurate technique to detect the surrounding inflammation, location of the tonsillolith, and the size. ${ }^{17} \mathrm{CBCT}$ has certain advantages, such as high spatial resolution, low cost, less image artifact, and low radiation doses compared with $\mathrm{CT} .{ }^{18}$

According to the literature, the prevalence of tonsillolith was quite lower in the studies performed on panoramic radiographs than the studies using CT or CBCT images. Icoz et al. ${ }^{12}$ evaluated the soft tissue calcifications observed on digital panoramic radiographs in a Turkish population and found the prevalence of tonsilloliths to be $2.5 \%$. In another panoramic study performed by Aghdasi et al. ${ }^{19}$, it was reported that the prevalence of tonsilloliths was $4.9 \%$ in an Iranian population. However, it was reported in the previous studies that the prevalence ranged from $18.6 \%$ to $46.1 \%$ in the studies using CT or CBCT images. ${ }^{11,20-24}$

The studies comparing panoramic radiography and CBCT images showed that the panoramic radiography detected fewer tonsilloliths when compared to the CBCT. Oda et al. ${ }^{25}$ compared panoramic radiography and $\mathrm{CBCT}$ images in the detection of tonsilloliths and demonstrated that the prevalence rate of tonsilloliths in the same Japanese subjects group was $7.7 \%$ in the panoramic radiographic images and $46.1 \%$ in the 
CBCT images. Takahashi et al. ${ }^{24}$ reported that the prevalence of tonsilloliths were $13.4 \%$ and $40.7 \%$ in 2244 Japanese subjects on the panoramic radiographic views and CT images, respectively. In another study performed by Centurion ${ }^{21}$ showed that the prevalence of tonsilloliths in the same Brazilian subjects group was $18 \%$ and $27 \%$ in panoramic and CBCT images, respectively. The higher prevalence of tonsilloliths in the CBCT images compared to panoramic radiographs proves that the $\mathrm{CBCT}$ is more accurate in detecting tonsilloliths. The lower tonsilloliths detection rate on panoramic radiographs, when compared to the CBCT, can probably be explained that the tonsilloliths outside the focal trough seem to be blurred and thus may not be detectable. Moreover, there can be difficulties in detecting tonsilloliths superimposed to the mandibular ramus.

The prevalence of tonsilloliths in the studies using CT or CBCT images showed differences in different geographic regions. In the CBCT studies performed by Price et al. ${ }^{26}$ and Allareddy et al. ${ }^{27}$, and Pette et al. ${ }^{28}$ (all in different American populations) the prevalence of tonsilloliths were reported to be $4.9 \%, 9.2 \%$, and $10.06 \%$, respectively. In a CBCT study carried out by Moshfeghi et al. ${ }^{11}$, it was reported that the prevalence rate of tonsilloliths was $18.6 \%$ in an Iranian population. In France, another study performed by Fauroux et al. $^{20}$ showed that tonsilloliths were present in $24.6 \%$ of CT images. Centurion et al. ${ }^{21}$ reported in their CBCT research that the prevalence rate of tonsilloliths was $27 \%$ in a Brazilian population sample. Ergun et al. ${ }^{22}$ reported that the prevalence of tonsilloliths was $32.2 \%$ in a Turkish population living in the Mediterranean region. In the studies performed by Takahashi et al. $^{23}$, Takahashi et al. $^{24}$, and Oda et al. ${ }^{25}$ (in different Japanese populations), the prevalence of tonsilloliths were reported to be $39.9 \%, 40.7 \%$, and $46.1 \%$, respectively. In the present study, the prevalence was $25.8 \%$ in a Turkish population sample living in the Aegean region. Based on the previous studies and our study, it can be concluded that the incidence of tonsilloliths may vary according to geographical regions and racial differences. Additionally, the wide range of prevalence rates between investigations might be explained by slice thickness differences.

Many authors have reported no significant impact of gender on the detection rate of tonsilloliths. ${ }^{11,12,14,19-21,25}$ In contrast, Kim et al. $^{7}$ observed a difference between the genders and males had a significantly higher number of tonsillar calcifications compared to females. In our research, no statistically significant difference was observed in the prevalence of tonsilloliths regarding sex, which is in agreement with many studies.

In the present research, a positive correlation was detected between the number of tonsilloliths and age; the prevalence of tonsilloliths tended to increase with age. Tonsillar calcifications were significantly more common in subjects older than 40 years old, while it was significantly lower in subjects younger than 21 years of age. Centurion et al. ${ }^{21}$ and Moshfeghi et al. ${ }^{11}$ found no significant correlation between the distribution of tonsilloliths and age. Kim et al. ${ }^{7}$ noted no relationship between the number of tonsilloliths and age. Fauroux et al. $^{20}$ found no significant difference in the prevalence of tonsilloliths among different age groups. Oda et al. ${ }^{25}$ found a significant correlation between the prevalence of tonsillolith and age. They also found a higher prevalence in over 40-year-old groups than under 40-year-old groups. However, they found no significant difference in the frequency among different age groups. Takahashi et al. ${ }^{23}$ reported that the prevalence rate of tonsilloliths increased with age. They showed that the prevalence rate in subjects aged 39 and younger was statistically lower than those older than 40. Aghdasi et al. ${ }^{19}$ reported that tonsilloliths more frequently found in subjects of 40-60 years of age. Moreover, Garay et al. ${ }^{29}$ informed a higher prevalence of tonsilloliths in subjects older than 40 years.

In our research, the number of subjects with unilateral tonsillolith was significantly higher than those with bilateral tonsilloliths. This finding was coherent with the previous study reported by Moshfeghi et al. ${ }^{11}$ However, in a panoramic study reported by Aghdasi et al. ${ }^{19}$ nearly half of the subjects had bilateral tonsillar calcifications. The superimposition of the other anatomical structures is common in the panoramic radiography and cause difficulties in interpreting the images. ${ }^{8}$ Unilateral tonsilloliths can be misinterpreted as bilateral in the panoramic radiographs because of their ghost images on the opposite side. ${ }^{15}$

In conclusion, the present study suggests that the tonsillolith detection rate is quite higher than what is reported in the previous studies with panoramic radiograph. According to our results, these calcifications affect approximately a quarter of the Aegean population. Tonsilloliths are age-related but sexindependent. These calcifications are more common in people older than 40 years of age. Although detection of tonsilloliths is not a common indication for CBCT, a detailed evaluation of the CBCT images provides a great contribution to the diagnosis of the soft tissue calcifications.

\section{Acknowledgments}

We thank R. A. Büşra Emir for assistance with statistical analysis and Frrat Selvi DDS, PhD in editing the text of the manuscript.

\section{Conflict of Interest}

The authors declare that they have no conflict of interest.

\section{Compliance of Ethical Statement}

The research was approved by the Izmir Katip Celebi University Non-Interventional Clinical Studies Institutional Review Board (Protocol number: 2018/301).

\section{Financial Disclosure/Funding}

This research did not receive any specific grant from funding agencies in the public, commercial, or not-for-profit sectors.

\section{Author Contributions}

FK: Critical revision; data analysis and interpretation; data collection; literature search, resources, materials; manuscript drafting/writing/editing; study conception and design, CÇ: Literature search, resources, materials; data collection; acquisition of resources, materials; data analysis and interpretation, data collection and materials; manuscript writing, EA: Critical revision; data analysis and interpretation; manuscript drafting/writing/editing; acquisition of resources/ project development; study conception and design.

\section{References}

1. Silvestre-Donat FJ, Pla-Mocholi A, Estelles-Ferriol E, MartinezMihi V. Giant tonsillolith: Report of a case. Med Oral Patol Oral Cir Bucal. 2005;10(3):239-242.

2. Mesolella M, Cimmino M, Di Martino M, Criscuoli G, Albanese L, Galli V. Tonsillolith. Case report and review of the literature. Acta Otorhinolaryngol Ital. 2004;24(5):302-307.

3. Mandel L. Multiple bilateral tonsilloliths: case report. J Oral Maxillofac Surg. $\quad 2008 ; 66(1): 148-150$. doi:10.1016/j.joms.2006.05.047 
4. Siber S, Hat J, Brakus I, et al. Tonsillolithiasis and orofacial pain. Gerodontology. 2012;29(2):e1157-1160. doi:10.1111/j.17412358.2011.00456.x

5. Ben Salem D, Guiu B, Duvillard C, Couaillier JF, Ricolfi F. Nasopharyngeal tonsillolith: a report of 31 cases. J Radiol. 2007;88(2):259-262.

6. Monsour PA, Romaniuk K, Hutchings RD. Soft tissue calcifications in the differential diagnosis of opacities superimposed over the mandible by dental panoramic radiography. Aust Dent J. 1991;36(2):94-101. doi:10.1111/j.1834-7819.1991.tb01336.x

7. Kim MJ, Kim JE, Huh KH, et al. Multidetector computed tomography imaging characteristics of asymptomatic palatine tonsilloliths: a retrospective study on 3886 examinations. Oral Surg Oral Med Oral Pathol Oral Radiol. 2018;125(6):693-698. doi:10.1016/j.oooo.2018.01.014

8. Sezer B, Tugsel Z, Bilgen C. An unusual tonsillolith. Oral Surg Oral Med Oral Pathol Oral Radiol Endod. 2003;95(4):471-473. doi:10.1067/moe.2003.65

9. Ludlow JB, Davies-Ludlow LE, Brooks SL, Howerton WB. Dosimetry of 3 CBCT devices for oral and maxillofacial radiology: CB Mercuray, NewTom 3G and i-CAT. Dentomaxillofac Radiol. 2006;35(4):219-226. doi:10.1259/dmfr/14340323

10. Missias EM, Nascimento E, Pontual M, et al. Prevalence of soft tissue calcifications in the maxillofacial region detected by cone beam CT. Oral Dis. 2018;24(4):628-637. doi:10.1111/odi.12815

11. Moshfeghi M, Navabi SS, Soltani P, Moaddabi A. Prevalence of tonsillolith on cone beam computed tomography images in patients attending shahid beheshti university of medical sciences. $\quad B r \quad J$ Med Med Res. 2017;19(11):1-6. doi:10.9734/BJMMR/2017/31718

12. Icoz D, Akgunlu F. Prevalence of detected soft tissue calcifications on digital panoramic radiographs. SRM Journal of Research in Dental Sciences. 2019;10(1):21. doi:10.4103/srmjrds.srmjrds_60_18

13. Ozcan E, Ural A, Oktemer TK, Alpaslan G. Bilateral tonsillolithiasis: a case report. Oral Surg Oral Med Oral Pathol Oral Radiol Endod. 2006;102(3):e17-18. doi:10.1016/j.tripleo.2006.01.010

14. Demiralp KÖ, Bayrak S, Çakmak EŞK. Prevalence and Characteristics af Palatine Tonsilloliths in Cone Beam Computed Tomography Images: A Retrospective Study. Kırıkkale Üniversitesi Tip Fakültesi Dergisi. 2017;19(2):97-102. doi:10.24938/kutfd.318036

15. Misirlioglu M, Nalcaci R, Adisen MZ, Yardimci S. Bilateral and pseudobilateral tonsilloliths: Three dimensional imaging with cone-beam computed tomography. Imaging Sci Dent. 2013;43(3):163-169. doi:10.5624/isd.2013.43.3.163

16. Hassen SM, Manson-Hing LR. A study of the zone of sharpness of three panoramic x-ray machines and the effect of screen speed on the sharpness zone. Oral Surg Oral Med Oral Pathol. 1982;54(2):242-249. doi:10.1016/0030-4220(82)90224-9
17. Lo RH, Chang KP, Chu ST. Upper airway obstruction caused by bilateral giant tonsilloliths. J Chin Med Assoc. 2011;74(7):329331. doi:10.1016/j.jcma.2011.05.011

18. Scarfe WC, Farman AG, Sukovic P. Clinical applications of cone-beam computed tomography in dental practice. J Can Dent Assoc. 2006;72(1):75-80.

19. Aghdasi MM, Valizadeh S, Amin-Tavakoli N, Bakhshandeh H. Tonsilolith in routine panoramic radiographies; is it a common incidental finding? Iran J Radiol. 2012;9(2):109-110. doi:10.5812/iranjradiol.7563

20. Fauroux MA, Mas C, Tramini P, Torres JH. Prevalence of palatine tonsilloliths: A retrospective study on 150 consecutive CT examinations. Dentomaxillofac Radiol. 2013;42(7):20120429. doi:10.1259/dmfr.20120429

21. Centurion BS, Imada TS, Pagin O, Capelozza AL, Lauris JR, Rubira-Bullen IR. How to assess tonsilloliths and styloid chain ossifications on cone beam computed tomography images. Oral Dis. 2013;19(5):473-478. doi:10.1111/odi.12026

22. Ergun $T$, Lakadamyali $H$. The prevalence and clinical importance of incidental soft-tissue findings in cervical CT scans of trauma population. Dentomaxillofac Radiol. 2013;42(10):20130216. doi:10.1259/dmfr.20130216

23. Takahashi A, Sugawara C, Kudoh T, et al. Prevalence and imaging characteristics of palatine tonsilloliths detected by CT in 2,873 consecutive patients. Scientific World Journal. 2014;2014. doi:10.1155/2014/940960

24. Takahashi A, Sugawara C, Kudoh T, et al. Prevalence and imaging characteristics of palatine tonsilloliths evaluated on 2244 pairs of panoramic radiographs and CT images. Clin Oral Investig. 2017;21(1):85-91. doi:10.1007/s00784-016-1752-0

25. Oda $M$, Kito $S$, Tanaka $T$, et al. Prevalence and imaging characteristics of detectable tonsilloliths on 482 pairs of consecutive CT and panoramic radiographs. BMC Oral Health. 2013;13:54. doi:10.1186/1472-6831-13-54

26. Price JB, Thaw KL, Tyndall DA, Ludlow JB, Padilla RJ. Incidental findings from cone beam computed tomography of the maxillofacial region: a descriptive retrospective study. Clin Oral Implants Res. 2012;23(11):1261-1268. doi:10.1111/j.16000501.2011.02299.x

27. Allareddy V, Vincent SD, Hellstein JW, Qian F, Smoker WR, Ruprecht A. Incidental findings on cone beam computed tomography images. Int J Dent. 2012;2012:871532. doi: $10.1155 / 2012 / 871532$

28. Pette GA, Norkin FJ, Ganeles J, et al. Incidental findings from a retrospective study of 318 cone beam computed tomography consultation reports. Int $J$ Oral Maxillofac Implants. 2012;27(3):595-603.

29. Garay I, Netto HD, Olate S. Soft tissue calcified in mandibular angle area observed by means of panoramic radiography. Int $J$ Clin Exp Med. 2014;7(1):51-56. 